\section{THE NATIONAL INSTITUTE FOR RESEARCH IN DAIRYING, SHINFIELD REPORT FOR 1955}

COME years ago Dr. E. V. McCollum, an eminent American authority on nutrition, stated that "The people who achieved, who have become large, strong, vigorous people, who have reduced their infant mortality, who have the best trades in the world, who have an appreciation for art, literature and music, who are progressive in science and in every activity of the human intellect, are the people who have used liberal amounts of milk and its products"! Even though this may well be regarded by many as something of an over-statement, it is undoubtedly true that milk contains a greater number of the individual nutrients essential for health in man than any other single food. Calculations made a few years ago showed that home-produced milk, consumed in Great Britain as liquid milk, supplied some 17 per cent of the total protein and some 12 per cent of the total fat in the people's food, as well as important proportions of its minerals, vitamins and energy content. The gross value of the milk and milk products produced annually in Britain amounts at present to some $£ 400$ million. Apart from economic considerations, it is worth recalling that the milk secretion process itself is one of the chief physiological functions on which the very existence of mammalian life depends.

With facts like these in mind, it is most encouraging to read of the work that is being done and the progress that is being made at the National Institute for Research in Dairying, Shinfield, under the direction of Prof. H. D. Kay, whose most informative annual report for 1955 has been recently published*. Lists of staff, patrons, fellows and members of the Institute are given, from which it can be seen that the number on the staff of the Institute now exceeds three hundred and that about a hundred of them are graduates in some branch of science.

The report can be regarded as consisting in the main of three principal parts. The first of these is the foreword, which contains a short but valuable outline of some of the recent findings that have been made at the Institute. More than thirty individual items are referred to. This part of the report should be of special interest to those who want to know as briefly as possible, and in an immediately practical way, what advances were made in 1955 without having to read in detail about the work of the Institute as a whole.

The second, and by far the largest, part of the report gives an account of each of the eight principal departments of the Institute, and also discusses the work of the four smaller sections that deal with such a wide variety of subjects as isotopes, statistics, psychology, and liaison with the dairy industry. Some of the problems under investigation are of a very practical nature, such as the prevention of infestation of cheese by mites, and the effect of 'vacuum' level on the rate of milking by machine. Others are scientifically more fundamental and require for their elucidation the expert knowledge and training of research workers in bacteriology,

* University of Reading. National Institute for Research in Dairying : Report 1955. Pp. 148. (Shinfleld: National Institute for Research in Dairying, 1956.) 48. chemistry, physics, physiology, nutrition and engineering. Examples that might be cited of these fundamental researches are the work that is being done on the biochemistry and physiology of milk secretion with particular reference to the formation of fat and protein in the mammary gland, and the detailed study that is being made of the chemistry of the $\beta$-lactoglobulins in milk.

A third section of the report, which will prove of special value to many. readers, comes under the heading of library. It gives a list, with full titles and references, of the 151 papers that were published by members of the staff between October 1954 and September 1955. A mere glance at this formidable list will impress the reader with the great scope and importance of the researches that are being done by what is clearly a very capable and enthusiastic band of workers.

\section{THE BRITISH STEEL CASTINGS RESEARCH ASSOCIATION}

\section{ANNUAL REPORT}

$\mathrm{T}$ HE British Steel Castings Research Association is one of the newest of the research associations operating under the aegis of the Department of Scientific and Industrial Research; although now having produced its third annual report*, this co-operative research organization, before it became attached to the Department, had been operating for some years under the wing of the British Steel Founders' Association. These were formative years, but from the present report it is apparent that this young and virile research body has reached a promising stage of development ; and a new research station is in course of erection at a suitable site in Sheffield, the home of so many famous developments in the steel world.

The steel-founding industry in Britain would appear from this report to be a compact and co-operative industry, well able to uphold the best traditions of British engineering industry. Much of the work of the Association in its brief existence has been confined to work carried out in member foundries. This liaison would appear to be particularly good, advisory work being also done by the Association's staff. Further, extramural research has been supported at several universities, and work of considerable value has emerged from these activities.

In the early days of its existence, the parent body of the Association, known as the Research and Development Division of the British Steel Founders' Association, took over from the British Iron and Steel Research Association the work of the old Steel Castings Committee, which had been responsible for notable activities in the field of steel founding, in particular in regard to steel casting, moulding sand and furnace refractory practice. From the days of Boswell in the First World War, when the first scientific studies of British moulding sands were undertaken in a number of foundries, the steelfounding industry has applied progressively scientific methods to its moulding practice; the developments outlined represent, on the part of the steel-founding industry, the realization of the value of co-operative

* British Steel Castings Research Association. Third Annual Report, 1956. Pp. ii +26 . (The Association, Broomgrove Lodge,
Sheffield 10.) 